Print ISSN: 2288-4637 / Online ISSN 2288-4645

doi:10.13106/jafeb.2020.vol7.no12.337

\title{
Financial Stability of GCC Banks in the COVID-19 Crisis: A Simulation Approach
}

\author{
Sami AL-KHARUSI ${ }^{1}$, Sree Rama MURTHY²
}

Received: August 01, 2020 Revised: October 11, 2020 Accepted: November 05, 2020

\begin{abstract}
Stability and sustainability of the biggest banks in any country are extremely important. When big banks become unstable and vulnerable, they typically stop lending. The resulting credit squeeze pushes the economy into recession or a slow growth path. The present study examines the financial stability and sustainability of the 30 large banks operating in the six Gulf Cooperation Council countries. These banks represent $70 \%$ of the GCC banking market. Monte Carlo simulation was attempted assuming that key drivers can vary randomly by twenty percent on either side of the current values. The conclusions are drawn based on 300 simulation trails of the five-year forecast balance and income statement of each bank. Year 2020 is not favorable for the GCC countries because of the COVID-19 pandemic and low oil prices, though the future years may be better. The study identifies several banks, which may become financially unsustainable because the simulations indicate the possibility of negative profitability, unacceptably low capital ratios and potential for heavy credit losses during periods of economic turbulence, which is the current situation due to the COVID-19 pandemic. Through simulation the paper is able to throw light on which factors lead to bank instability and weakness.
\end{abstract}

Keywords: Financial Sustainability, Banks, Publicly Traded, Simulation, Gulf Cooperation Council

JEL Classification Code: C15, G17, G21, L25

\section{Introduction}

Stability and sustainability of the biggest banks in any country are extremely important for financial sector stability and real economic growth. When big banks become unstable and vulnerable, they typically stop lending. The resulting credit squeeze pushes the economy into recession or a slow growth path. The purpose of this paper is to analyze and forecast the financial statements of large commercial banks operating in the six Gulf Cooperation Council countries (Bahrain, Kuwait, Oman, Qatar, Saudi Arabia, and United Arab Emirates). Since forecasts are based on certain assumptions about the

${ }^{1}$ First Author and Corresponding Author. [1] Assistant Dean, Training and Community Services [2] Assistant Professor, Economics and Finance Department, Sultan Qaboos University, Oman [Postal Address: PO Box 20, PC 123, Muscat, Oman]

Email: ksami@squ.edu.om

${ }^{2}$ Assistant Professor, Economics and Finance Department, Sultan Qaboos University, Oman. Email: murthy@squ.edu.om

(c) Copyright: The Author(s)

This is an Open Access article distributed under the terms of the Creative Commons Attribution Non-Commercial License (https://creativecommons.org/licenses/by-nc/4.0/) which permits unrestricted non-commercial use, distribution, and reproduction in any medium, provided the original work is properly cited. surrounding economic environment, and one can never be certain about how the future will evolve, the paper uses simulation to forecast financial statements assuming that the future macroeconomic trends in these countries may be either favorable or unfavorable. Year 2020 is not favorable for the GCC countries because of the COVID-19 pandemic and the low oil prices, though the future years may be better. Through simulation the paper is able to throw light on which factors lead to bank instability and weakness.

\section{Review of Literature}

There are large number of papers that examined the issue of financial stability and sustainability of commercial banks. The papers can be broadly divided into those that looked at financial ratios and bank stability and, bank business model and stability. Papers that looked at the relationship between business model and bank stability (Altunbas et al., 2011; Ayadi et al., 2011; Kohler, 2015; Mergaerts \& Vennet, 2016; Rungporn et al., 2017; Rachman et al., 2018; Tran et al., 2020; Duong et al., 2020) conclude that retail banking model leads to stability, while wholesale banking and trading activity oriented banking is not sustainable. Most of the studies that 
looked at the relationship between macroeconomic/financial ratios and bank stability (Mehra, 1996; Basel Committee, 2013; Lee \& Brahmasrene, 2018; Kunitsyna et al., 2018; Hafiz, 2019; Pisedtasalasai \& Eedirisuriya, 2020) use a variety of econometric techniques (such as panel regression and GMM) and conclude that capital adequacy, liquidity and credit risk are key determinants of stability.

An important contribution of the present paper is the use of Monte Carlo simulation method to examine the behavior of individual commercial bank financial statements so as to arrive at the impact of macroeconomic uncertainty on the stability and sustainability of the banks.

Kunitsyna et al. (2018) is one of the few papers which used the Monte Carlo simulation to examine the issue of financial sustainability of commercial banks, but the Kunitsyna paper focuses on the link between reputation risk and financial sustainability, while the focus of the present paper is on financial sustainability and long term stability of banks during periods of economic turbulence.

\section{Data and Methodology}

The study is based on balance sheet simulation of listed commercial banks operating in the six Gulf Cooperation Council(GCC) countries: Bahrain, Kuwait, Oman, Qatar, Saudi Arabia, and United Arab Emirates (UAE). Top commercial banks in each of these countries were selected on the basis of the size of their total assets. Only publicly-traded commercial banks that are listed in the stock markets of their own countries are included in the study. The study covers 30 listed GCC commercial banks, which account for more than $70 \%$ of the banking sector market share in their respective countries.

Data for the purpose of the study was drawn from published balance sheets and income statements of the listed commercial banks included in the study. A two-step method was adopted for arriving at the Monte Carlo simulation results. Using past financial statement data the balance sheet and income statement of each bank was forecasted for the next five years up to year 2023. Key drivers in the balance sheet forecasting process were loan growth, deposit growth, loan loss provisions and interest yields. Cost efficiencies derived from use of technological innovation is an important part of the forecasting methodology used in this study. In the second step, Monte Carlo simulation (Anderson et al., 2018, Vose, 2008, Evans \& Olson, 2001) was attempted assuming that key drivers (such as loan growth, etc.) can vary randomly by twenty percent on either side of the current values. For the purpose of modeling technological innovation, fintech and technology adoption it was assumed the non-interest expenses keep getting reduced randomly over the forecast period.

The balance sheet forecasts for each bank form the basis for arriving at the following key performance ratios in each simulation trial run:
- return on equity (ROE)

- return on assets (ROA)

- equity to total assets (EQTA)

- loan loss provisions to total loans (LLP)

- liquid assets to total assets (LIQ)

Simulation results are based on a total of 300 trials for each bank forecasted balance sheet. The behavior of the key ratios is reported in the next section in terms of average, standard deviation, maximum value and minimum value obtained during the simulation trials. A four digit coding method was used for naming the banks in the results tables reported below. The first two digits are based on the name of the bank and the last two digits refer to the country to which they belong. Bahrain - BH, Kuwait - KW, Oman - OM, Qatar - QA, Saudi Arabia - SA, and United Arab Emirates - AE. For example, Bank Muscat, listed in the Muscat Securities Market, is shown as BMOM.

\section{Simulation Results}

The results of the simulation analysis for the 30 banks included in the study are presented in the tables given below.

\subsection{Capital Strength}

Equity to total assets is a proxy for how well capitalized a bank is, and higher the number the better. "Mean" value of equity to total assets reported in Table 1 shows the average obtained over 300 simulation trials of the five year forecasts of the bank's balance sheet and income statement. High capital ratio indicates that the bank is very strong and can survive recessions and downturns. High levels of capital are also very useful for survival of a bank when it is facing severe competition and losing market share temporarily. BSSA a Saudi Arabian bank has the best capital ratios during the forecast period (2019 to 2023). All Saudi banks have strong capital ratios - average capital ratios are more than $20 \%$ and the minimum capital ratio is 9.50 during the simulation trials.

The results indicate that several UAE and Bahrain banks and one Kuwaiti bank have weak capital ratios with minimum capital ratio getting pushed to below $5 \%$ in simulation trials. In fact, two banks showed minimum capital ratio as low as $1 \%$. Two banks, ENAE and BUKW, have low minimum capital ratios and low profitability. If one combines the capital ratio simulations results with profit simulation results (Table 2 Return on equity) the conclusion is that losses occurring over several years push down equity levels, and therefore capital ratios, bringing a bank closer to bankruptcy. Raising fresh capital - Tier 1 equity capital or Tier 2 subordinated debt (such as perpetual bonds) can solve the problem provided the bank is able to improve its profit margins. Merger with a better-capitalized bank is another available option. 
Table 1: Capital Ratio: Equity to Total Assets (\%) - Monte Carlo Simulation Results*

\begin{tabular}{|c|c|c|c|c|c|}
\hline Bank & Country & Mean & Standard Deviation & Maximum Value & Minimum Value \\
\hline ADAE & UAE & 16.14 & 6.84 & 41.22 & 7.86 \\
\hline FBAE & UAE & 17.36 & 7.45 & 42.68 & 7.90 \\
\hline ENAE & UAE & 8.58 & 3.93 & 19.76 & 1.89 \\
\hline CBAE & UAE & 11.11 & 3.90 & 21.61 & 5.90 \\
\hline RAAE & UAE & 15.69 & 6.28 & 36.12 & 8.02 \\
\hline QNQA & Qatar & 26.40 & 12.97 & 75.14 & 12.50 \\
\hline CBQA & Qatar & 11.18 & 4.29 & 25.81 & 4.85 \\
\hline DOQA & Qatar & 17.76 & 8.50 & 46.78 & 7.64 \\
\hline AKQA & Qatar & 15.81 & 6.84 & 39.04 & 7.82 \\
\hline AHQA & Qatar & 29.98 & 14.91 & 73.89 & 13.03 \\
\hline NCSA & Saudi Arabia & 21.82 & 11.22 & 66.29 & 9.92 \\
\hline ARSA & Saudi Arabia & 22.64 & 11.10 & 55.04 & 9.50 \\
\hline SASA & Saudi Arabia & 28.30 & 14.73 & 81.78 & 10.80 \\
\hline RISA & Saudi Arabia & 28.45 & 13.81 & 77.82 & 13.27 \\
\hline BSSA & Saudi Arabia & 29.03 & 13.28 & 74.42 & 12.07 \\
\hline SBSA & Saudi Arabia & 24.34 & 12.35 & 67.81 & 10.94 \\
\hline AUBH & Bahrain & 18.57 & 7.81 & 45.85 & 9.24 \\
\hline $\mathrm{GIBH}$ & Bahrain & 6.16 & 3.02 & 15.88 & 1.01 \\
\hline $\mathrm{NBBH}$ & Bahrain & 15.31 & 5.72 & 35.32 & 7.69 \\
\hline BKBH & Bahrain & 14.95 & 8.48 & 37.18 & 6.08 \\
\hline NBKW & Kuwait & 13.84 & 5.35 & 28.96 & 7.43 \\
\hline BUKW & Kuwait & 10.34 & 5.47 & 31.42 & 1.70 \\
\hline AHKW & Kuwait & 16.30 & 6.50 & 38.03 & 7.47 \\
\hline GBKW & Kuwait & 9.68 & 3.97 & 24.48 & 5.25 \\
\hline CBKW & Kuwait & 19.51 & 9.19 & 47.11 & 8.30 \\
\hline BMOM & Oman & 25.44 & 11.18 & 53.24 & 11.49 \\
\hline HSOM & Oman & 16.56 & 8.86 & 48.24 & 7.25 \\
\hline BDOM & Oman & 14.60 & 5.64 & 29.97 & 7.25 \\
\hline NBOM & Oman & 20.99 & 10.29 & 57.61 & 8.09 \\
\hline SIOM & Oman & 11.87 & 4.84 & 27.10 & 6.04 \\
\hline
\end{tabular}

\subsection{Profitability and Efficiency}

Return on equity (net income after tax divided by total equity) is considered an excellent indicator of profitability. The simulation results for this profit ratio are presented in Table 2. From a financial stability and sustainability point of view this ratio is the most important one. A bank experiencing poor profitability soon becomes financially unsustainable. There could be many reasons for low profits. Poor credit quality and non-performing loans is an important reason. Another could be asset management inefficiencies, thin interest margins and high operating costs.

Eighteen banks out of the 30 banks included in this study exhibited average ROEs in excess of $10 \%$ in the simulation trials, and three banks came out with average ROE in excess of $20 \%$. Only in case of one bank, GIBH, the simulation results threw up a negative average ROE. Further in case of this bank the study finds in 56\% of the simulation trials the return on equity turned out to be negative. Eleven banks out of the 30 banks had negative ROEs in more than $20 \%$ of the simulation trials, indicating lack of financial sustainability in the longer run. Three banks - ARSA, NBBH and BMOM - did not have even one negative ROE in all the simulation trials, and can therefore be classified as the strongest from financial sustainability point of view. Another three banks had less than 5\% negative ROEs in the simulation runs, and can be classified as fairly strong banks. 
Table 2: Return on Equity (\%) - Monte Carlo Simulation Results

\begin{tabular}{|c|c|c|c|c|c|}
\hline Bank & Country & Mean & Standard Deviation & Maximum Value & Minimum Value \\
\hline ADAE & UAE & 13.20 & 13.06 & 28.56 & -19.82 \\
\hline FBAE & UAE & 10.84 & 9.2 & 28.2 & -10.03 \\
\hline ENAE & UAE & 3.57 & 24.1 & 34.4 & -115.39@ \\
\hline CBAE & UAE & 18.55 & 14.25 & 43.75 & -14.73 \\
\hline RAAE & UAE & 21.55 & 11.78 & 43.80 & $-2.14^{* *}$ \\
\hline QNQA & Qatar & 8.19 & 17.70 & 33.11 & -50.03@ \\
\hline CBQA & Qatar & 12.34 & 18.75 & 38.97 & -80.16@ \\
\hline DOQA & Qatar & 5.41 & 15.07 & 28.97 & -30.80@ \\
\hline AKQA & Qatar & 8.77 & 19.08 & 35.95 & -38.69@ \\
\hline AHQA & Qatar & 15.72 & 10.11 & 31.27 & -9.96 \\
\hline NCSA & Saudi Arabia & 13.74 & 11.03 & 36.00 & -7.44 \\
\hline ARSA & Saudi Arabia & 19.56 & 9.32 & 39.03 & $4.93^{*}$ \\
\hline SASA & Saudi Arabia & 9.93 & 7.78 & 27.51 & $-2.17^{* *}$ \\
\hline RISA & Saudi Arabia & 9.10 & 7.04 & 23.81 & -4.34 \\
\hline BSSA & Saudi Arabia & 10.72 & 8.07 & 25.48 & -11.55 \\
\hline SBSA & Saudi Arabia & 10.97 & 8.00 & 28.46 & -3.49 \\
\hline AUBH & Bahrain & 29.34 & 28.39 & 98.68 & -15.89 \\
\hline $\mathrm{GIBH}$ & Bahrain & -26.20 & 73.15 & 29.69 & -454.4@ \\
\hline $\mathrm{NBBH}$ & Bahrain & 28.18 & 12.67 & 50.31 & $2.17^{*}$ \\
\hline $\mathrm{BKBH}$ & Bahrain & 11.24 & 17.65 & 44.81 & -27.29@ \\
\hline NBKW & Kuwait & 15.39 & 12.67 & 36.15 & -18.38 \\
\hline BUKW & Kuwait & 6.81 & 28.39 & 41.75 & -115.27@ \\
\hline AHKW & Kuwait & 9.15 & 16.07 & 36.44 & -43.30@ \\
\hline GBKW & Kuwait & 16.54 & 16.12 & 42.81 & -35.80 \\
\hline CBKW & Kuwait & 12.15 & 9.33 & 29.93 & -6.36 \\
\hline BMOM & Oman & 13.53 & 8.62 & 30.60 & $1.30^{*}$ \\
\hline HSOM & Oman & 8.56 & 6.38 & 21.77 & $-2.04^{* *}$ \\
\hline BDOM & Oman & 14.79 & 15.72 & 36.24 & -43.20 \\
\hline NBOM & Oman & 7.43 & 12.11 & 29.41 & -30.97@ \\
\hline SIOM & Oman & 8.36 & 19.93 & 41.52 & -52.8@ \\
\hline \multicolumn{6}{|c|}{$\begin{array}{l}\text { \# based on } 300 \text { simulation trails of } 5 \text { year forecasted balance and income statement of each bank } \\
{ }^{*} \text { Strong: }<0 \% \text { negative ROEs in simulation trials } \\
{ }^{*} \text { Fairly Stable: }<5 \% \text { negative ROEs in simulation trials } \\
@ \text { Weak and possibly unsustainable: }>20 \% \text { negative ROEs in simulation trials }\end{array}$} \\
\hline
\end{tabular}

Return on assets (ROA) is a well-accepted measure of bank efficiency. Return on assets is good proxy for both asset efficiency as well as profitability. Simulation results for return on assets are presented in Table 3. The simulation results of ROA are very similar to the ROE results reported in Table 2, because both measures are based on the net income after tax. Three banks that reported average ROAs in excess of 3\% - ABQA, ARSA and NBBH - can be classified as the best in terms of asset efficiency. Only one bank, GIBH, showed a negative average ROA. Further this bank had a negative ROA in $64 \%$ of the simulation trails. We can conclude that unless corrective action is taken such banks are likely to become financially unsustainable in the long run. 
Table 3: Return on Assets (\%) - Monte Carlo Simulation Results

\begin{tabular}{|c|c|c|c|c|c|}
\hline Bank & Country & Mean & Standard Deviation & Maximum Value & Minimum Value \\
\hline ADAE & UAE & 2.29 & 1.63 & 4.49 & -1.88 \\
\hline FBAE & UAE & 1.66 & 1.03 & 3.18 & -1.31 \\
\hline ENAE & UAE & 0.65 & 1.47 & 3.53 & -2.26 \\
\hline CBAE & UAE & 2.19 & 1.15 & 3.81 & -1.61 \\
\hline RAAE & UAE & 2.71 & 1.35 & 4.99 & -0.42 \\
\hline QNQA & Qatar & 2.77 & 2.88 & 6.08 & -6.19 \\
\hline CBQA & Qatar & 1.35 & 1.63 & 3.74 & -2.76 \\
\hline DOQA & Qatar & 1.09 & 1.98 & 4.16 & -3.63 \\
\hline AKQA & Qatar & 1.18 & 2.29 & 4.15 & -3.70 \\
\hline AHQA & Qatar & 3.54 & 2.04 & 5.71 & -2.59 \\
\hline NCSA & Saudi Arabia & 2.75 & 1.88 & 5.56 & -0.86 \\
\hline ARSA & Saudi Arabia & 3.37 & 0.91 & 4.73 & 0.94 \\
\hline SASA & Saudi Arabia & 2.77 & 1.34 & 5.06 & -0.31 \\
\hline RISA & Saudi Arabia & 2.11 & 1.8 & 4.19 & -1.04 \\
\hline BSSA & Saudi Arabia & 2.12 & 1.69 & 4.50 & -1.97 \\
\hline SBSA & Saudi Arabia & 2.24 & 1.32 & 4.39 & -0.04 \\
\hline AUBH & Bahrain & 2.41 & 1.83 & 4.60 & -4.33 \\
\hline $\mathrm{GIBH}$ & Bahrain & -0.71 & 1.56 & 1.90 & -4.77 \\
\hline $\mathrm{NBBH}$ & Bahrain & 4.46 & 1.67 & 7.18 & 0.041 \\
\hline BKBH & Bahrain & 1.38 & 1.93 & 5.31 & -1.81 \\
\hline NBKW & Kuwait & 1.55 & 1.25 & 3.50 & -1.04 \\
\hline BUKW & Kuwait & 0.56 & 2.26 & 4.46 & -4.82 \\
\hline AHKW & Kuwait & 1.35 & 1.99 & 4.04 & -4.07 \\
\hline GBKW & Kuwait & 1.55 & 1.27 & 3.28 & -2.57 \\
\hline CBKW & Kuwait & 1.87 & 1.37 & 3.77 & -1.40 \\
\hline BMOM & Oman & 2.92 & 0.76 & 3.78 & -0.41 \\
\hline HSOM & Oman & 1.10 & 0.71 & 2.30 & -0.50 \\
\hline BDOM & Oman & 1.70 & 1.67 & 3.66 & -4.04 \\
\hline NBOM & Oman & 1.22 & 1.93 & 3.72 & -3.84 \\
\hline SIOM & Oman & 1.68 & 2.06 & 3.98 & -4.23 \\
\hline
\end{tabular}

\subsection{Credit Quality and Non-Performing Loans}

A very important indicator of a bank's financial sustainability is its credit quality. A bank with poor credit quality will have a high percentage of non-performing loans and therefore the ratio of annual loan loss provisions to total loans (LLP) will be high. Among the various reasons for financial unsustainability of a bank, viz., thin interest margins, excessive overhead costs and high percentage of non-performing loans, the most important is, no doubt, credit quality. Banking is primarily a business of taking deposits and giving loans, and a bank that is not able to recover the loans is doomed to be a failure. Table 4 reports the results of simulation trials in terms of average LLP (ratio of loan loss provisions to total loans). A high percentage indicates that the bank is in a problem. Six banks out of the 30 had average LLP ratios in excess of $1.65 \%$, indicating they are likely to become problem banks, which are financially unsustainable. The credit quality of one UAE bank (RAAE) is particularly worrying. It is interesting to note that these problem banks are distributed among different GCC countries and do not belong to any one country. GBKW is the best bank with an average LLP ratio of just $0.09 \%$. In terms of credit quality, the simulation results indicate a top rated bank will have average loan loss provisions of less than $1.0 \%$ of total loans. 
Table 4: Loan Loss Provisions to Total Assets (\%) - Monte Carlo Simulation Results

\begin{tabular}{|c|c|c|c|c|c|}
\hline Bank & Country & Mean & Standard Deviation & Maximum Value & Minimum Value \\
\hline ADAE & UAE & 1.02 & 0.12 & 1.22 & 0.82 \\
\hline FBAE & UAE & 0.62 & 0.07 & 0.75 & 0.51 \\
\hline ENAE & UAE & 0.86 & 0.10 & 1.02 & 0.69 \\
\hline CBAE & UAE & 1.70 & 0.18 & 2.02 & 1.36 \\
\hline RAAE & UAE & 4.86 & 0.53 & 5.74 & 3.90 \\
\hline QNQA & Qatar & 0.48 & 0.06 & 0.57 & 0.38 \\
\hline CBQA & Qatar & 1.91 & 0.21 & 2.28 & 1.53 \\
\hline DOQA & Qatar & 0.99 & 0.11 & 1.19 & 0.79 \\
\hline AKQA & Qatar & 0.87 & 0.11 & 1.19 & 0.79 \\
\hline AHQA & Qatar & 0.24 & 0.03 & 0.30 & 0.20 \\
\hline NCSA & Saudi Arabia & 0.75 & 0.090 & 0.90 & 0.60 \\
\hline ARSA & Saudi Arabia & 0.66 & 0.08 & 0.79 & 0.53 \\
\hline SASA & Saudi Arabia & 0.24 & 0.03 & 0.29 & 0.20 \\
\hline RISA & Saudi Arabia & 0.90 & 0.10 & 1.06 & 0.71 \\
\hline BSSA & Saudi Arabia & 0.53 & 0.06 & 0.65 & 0.44 \\
\hline SBSA & Saudi Arabia & 0.85 & 0.10 & 1.02 & 0.69 \\
\hline AUBH & Bahrain & 0.44 & 0.05 & 0.53 & 0.36 \\
\hline $\mathrm{GIBH}$ & Bahrain & 0.43 & 0.05 & 0.52 & 0.35 \\
\hline $\mathrm{NBBH}$ & Bahrain & 0.85 & 0.10 & 1.01 & 0.68 \\
\hline $\mathrm{BKBH}$ & Bahrain & 1.65 & 0.18 & 1.98 & 1.33 \\
\hline NBKW & Kuwait & 1.30 & 0.15 & 1.55 & 1.04 \\
\hline BUKW & Kuwait & 0.94 & 0.10 & 1.13 & 0.76 \\
\hline AHKW & Kuwait & 1.88 & 0.22 & 2.24 & 1.50 \\
\hline GBKW & Kuwait & 0.09 & 0.01 & 0.11 & 0.07 \\
\hline CBKW & Kuwait & 2.11 & 0.24 & 2.47 & 1.66 \\
\hline BMOM & Oman & 0.87 & 0.10 & 1.03 & 0.69 \\
\hline HSOM & Oman & 0.39 & 0.04 & 0.47 & 0.32 \\
\hline BDOM & Oman & 0.54 & 0.07 & 0.65 & 0.43 \\
\hline NBOM & Oman & 0.93 & 0.10 & 1.12 & 0.76 \\
\hline SIOM & Oman & 0.39 & 0.05 & 0.46 & 0.31 \\
\hline
\end{tabular}

\subsection{Liquidity}

The four indicators discussed above primarily impact the medium to long term sustainability of a bank. However, in the short run liquidity becomes important. A bank that suffers from a liquidity crunch will easily go bankrupt, especially if it is not able to borrow in the money market. High liquidity levels are also important during periods of financial crisis such as the 2008 global economic crisis. Liquid assets ratio (LIQ) is used to measure the liquidity in this study. Liquid assets ratio is defined as cash plus government securities plus due from banks as a ratio of total assets. Table 5 reports the simulation results. Average liquidity as per the simulation results is high in most of the GCC banks, with most banks reporting a liquidity ratio is excess of $20 \%$ during the forecast period. Only one bank GBKW- has a minimum liquidity ratio of $3.5 \%$, which is quite low. The simulation results shown in Table 5 indicate that bank ENAE had the highest average liquidity ratio at $58.5 \%$ and bank BMOM had the lowest average liquidity at $18.33 \%$. Minimum liquidity levels touched by banks during simulation trials are also at acceptable levels, indicating that lack of financial sustainability due to poor liquidity is not a problem issue for GCC banks. 
Table 5: Liquid Assets to Total assets (\%) - Monte Carlo Simulation Result

\begin{tabular}{|c|c|c|c|c|c|}
\hline Bank & Country & Mean & Standard Deviation & Maximum Value & Minimum Value \\
\hline ADAE & UAE & 34.26 & 17.42 & 78.63 & 11.09 \\
\hline FBAE & UAE & 35.87 & 17.96 & 79.16 & 7.97 \\
\hline ENAE & UAE & 58.58 & 16.25 & 90.09 & 3 \\
\hline CBAE & UAE & 27.56 & 14.37 & 62.69 & 8.20 \\
\hline RAAE & UAE & 31.54 & 13.56 & 68.60 & 12.86 \\
\hline QNQA & Qatar & 25.33 & 13.51 & 63.54 & 9.24 \\
\hline CBQA & Qatar & 28.25 & 11.71 & 60.66 & 12.48 \\
\hline DOQA & Qatar & 41.95 & 16.00 & 76.41 & 16.34 \\
\hline AKQA & Qatar & 39.82 & 14.86 & 77.98 & 18.20 \\
\hline AHQA & Qatar & 22.65 & 12.44 & 64.25 & 8.72 \\
\hline NCSA & Saudi Arabia & 40.42 & 17.55 & 80.16 & 12.62 \\
\hline ARSA & Saudi Arabia & 28.41 & 15.95 & 67.55 & 7.22 \\
\hline SASA & Saudi Arabia & 51.90 & 20.13 & 91.22 & 17.08 \\
\hline RISA & Saudi Arabia & 41.83 & 19.68 & 81.64 & 10.92 \\
\hline BSSA & Saudi Arabia & 38.97 & 16.42 & 80.23 & 15.84 \\
\hline SBSA & Saudi Arabia & 45.54 & 18.18 & 85.02 & 13.27 \\
\hline AUBH & Bahrain & 18.82 & 8.53 & 51.10 & 9.30 \\
\hline $\mathrm{GIBH}$ & Bahrain & 52.09 & 12.35 & 84.32 & 33.25 \\
\hline $\mathrm{NBBH}$ & Bahrain & 46.54 & 16.93 & 84.67 & 18.16 \\
\hline $\mathrm{BKBH}$ & Bahrain & 57.05 & 17.41 & 86.94 & 21.95 \\
\hline NBKW & Kuwait & 41.94 & 14.97 & 73.21 & 17.43 \\
\hline BUKW & Kuwait & 41.95 & 16.59 & 82.37 & 17.82 \\
\hline AHKW & Kuwait & 22.87 & 13.24 & 54.55 & 5.51 \\
\hline GBKW & Kuwait & 23.90 & 13.11 & 59.28 & 3.50 \\
\hline CBKW & Kuwait & 46.30 & 16.59 & 86.49 & 23.86 \\
\hline BMOM & Oman & 18.33 & 9.67 & 50.76 & 7.14 \\
\hline HSOM & Oman & 45.08 & 20.34 & 86.44 & 8.76 \\
\hline BDOM & Oman & 23.36 & 11.46 & 58.66 & 10.38 \\
\hline NBOM & Oman & 26.39 & 14.67 & 68.28 & 7.07 \\
\hline SIOM & Oman & 28.29 & 13.85 & 64.12 & 7.32 \\
\hline
\end{tabular}

\section{Conclusions}

The present study examines the financial stability and sustainability of the 30 large banks operating in the six Gulf Cooperation Council countries. These banks represent $70 \%$ of the GCC banking market. A two-step method was adopted for arriving at the Monte Carlo simulation results. Using past financial statement data the balance sheet and income statement of each bank was forecasted for the next five years up to year 2023. Key drivers in the balance sheet forecasting process were loan growth, deposit growth, loan loss provisions and interest yields. In the second step, Monte Carlo simulation was attempted assuming that key drivers can vary randomly by twenty percent on either side of the current values. The conclusions are drawn based on 300 simulation trails of the 5 year forecasted balance and income statement of each bank.

Eleven banks out of the 30 banks had negative ROEs in more than $20 \%$ of the simulation trials, indicating lack of financial sustainability in the longer run. The results 
indicate that several GCC banks have weak capital ratios with minimum capital ratio getting pushed to below $5 \%$ in simulation trials. In fact, two banks showed minimum capital ratio as low as $1 \%$. Three banks that reported average ROAs in excess of $3 \%$ can be classified as the best in terms of asset efficiency. Only one bank showed a negative average ROA. Furthermore, this bank had a negative ROA in $64 \%$ of the simulation trails. From credit quality point of view, six banks out of the 30 had average loan loss ratios in excess of $1.65 \%$, indicating they are likely to become financially unsustainable. Minimum liquidity levels touched by banks during simulation trials are also at acceptable levels, indicating that lack of financial sustainability due to poor liquidity is not a problem issue for GCC banks.

A major contribution of the present study, unlike econometric studies based on past data, is its ability to identify banks which may become financially unsustainable in the face of future uncertainties and macroeconomic turbulence which is the very true of the current situation in the Gulf region due to the COVID-19 pandemic and low oil prices. The results of the study are useful both for internal management of banks as well as for regulators who must ensure that these large banks do not fail.

\section{References}

Altunbas, Y., Manganelli, S., \& Marques-Ibanez, D. (2011). Bank risk during the financial crisis: do business models matter?. ECB Working Paper Series, No. 1394, November.

Ayadi, R., Arbak, E., \& de Groen, W. P. (2011). Business Models in European Banking: A pre-and post-crisis screening. Centre for European Policy Studies, Brussels: CEPS.

Anderson, D. R., \& Sweeney, D. J. (2018). An Introduction to Management Science: Quantitative Approaches to Decision Making (15 th $\mathrm{ed}$.). Boston, MA: Cengage.

Basel Committee on Banking Supervision. (2013). Global systemically important banks: updated assessment methodology and the higher loss absorbency requirement. Retrieved October 1, 2020 from https://www.bis.org/publ/bcbs255.htm

Duong, T. T. N., Phan, H. T., Hoang, T. N., \& Vo, T. T. T. (2020). The Effect of Financial Restructuring on the Overall Financial Performance of the Commercial Banks in Vietnam. Journal of Asian Finance, Economics and Business, 7(9), 75-84. https:// doi.org/10.13106/jafeb.2020.vol7.no9.075
Evans, J. R., \& Olson, D. L. (2001). Introduction to Simulation and Risk Analysis (2nd ed.). Upper Saddle River, NJ: Prentice Hall.

Hafiz, W. (2019). Risk Management, Capital Adequacy and Audit Quality for Financial Stability, Asian Economic and Financial Review, 9(6), 654-664.

Köhler, M. (2015). Which banks are more risky? The impact of business models on bank stability. Journal of Financial Stability, 16, 195-212.

Kunitsyna, N., Britchenko, I., \& Kunitsyn, I. (2018). Reputation risks, value of losses and financial sustainability of commercial banks. Entrepreneurship and Sustainability Issues, 5(4), 943955.

Lee, J. W., \& Brahmasrene, T. (2018). An Exploration of Dynamical Relationships between Macroeconomic Variables and Stock Prices in Korea. Journal of Asian Finance, Economics and Business, 5(3), 7-17. http://doi.org/10.13106/jafeb.2018.vol5. no3.7

Mergaerts, F., \& vander Vennet, R. (2016). Business models and bank performance: A long-term perspective. Journal of Financial Stability, 22(1), 57-75.

Mehra, A. (1996). Resource and Market Based Determinants of Performance in the U.S. Banking Industry. Strategic Management Journal, 17(4), 307-322.

Rungporn, R., Nikola, T., Kostas, T., \& Villegas, A. (2017). Bank business models: popularity and performance. BIS Working Papers No 682.

Pisedtasalasai, A., \& Eedirisuriya, P. (2020). Diversification and Performance of Sri Lankan Banks. Journal of Asian Finance, Economics and Business, 7(9), 1-10. https://doi.org/10.13106/ jafeb.2020.vol7.no9.001

Rachman, R. A., Kadarusman, Y. B., Anggriono, K., \& Setiadi, R. (2018). Bank-specific Factors Affecting Non-Performing Loans in Developing Countries: Case Study of Indonesia. Journal of Asian Finance, Economics and Business, 5(2), 35-42. https:// doi.org/10.13106/jafeb.2018.vol5.no2.35

Vose, D. (2008). Risk Analysis: A Quantitative Guide. Hoboken, NJ: Wiley

Tran, T. Q., Ly, A. H., \& Nguyen, D. K. N. (2020). Relationship between Ownership Structures and Earnings Management Behavior in Vietnamese Commercial Banks. Journal of Asian Finance, Economics and Business, 7(9), 401-407. https://doi. org/10.13106/jafeb.2020.vol7.no9.401 